\title{
Variation and trends in incidence of childhood diabetes in Europe
}

\author{
EURODIAB ACE Study Group*
}

\section{Summary}

Background To study the epidemiology of childhood-onset type 1 insulin-dependent diabetes in Europe, the EURODIAB collaborative group established in 1988 prospective geographically-defined registers of new cases diagnosed under 15 years of age. This report is based on 16362 cases registered during the period 1989-94 by 44 centres representing most European countries and Israel and covering a population of about 28 million children

Methods Multiple sources of ascertainment were used in most centres to validate the completeness of registration by the capture-recapture method. Trends in incidence during the period were analysed by Poisson regression, the data from centres within each country being pooled.

Findings The standardised average annual incidence rate during the period 1989-94 ranged from 3.2 cases per 100000 per year in the Former Yugoslav Republic of Macedonia to 40.2 cases per 100000 per year in two regions of Finland. By pooling over all centres, the annual rate of increase in incidence was 3.4\% (95\% Cl 2.5-4.4\%), but in some central European countries it was more rapid than this. Pooled over centres and sexes, the rates of increase were $6.3 \%(4 \cdot 1-8.5 \%)$ for children aged $0-4$ years, $3.1 \%(1.5-4.8 \%)$ for $5-9$ years, and $2.4 \%(1.0-3 \cdot 8 \%)$ for 10-14 years.

Interpretation The results confirm a very wide range of incidence rates within Europe and show that the increase in incidence during the period varied from country to country. The rapid rate of increase in children aged under 5 years is of particular concern.

Lancet 2000; 355: 873-876
*Members of group given at the end of article

Correspondence to: Dr C C Patterson, Department of Epidemiology and Public Health, Queen's University of Belfast, Royal Victoria Hospital, Grosvenor Road, Belfast BT12 6BJ, UK (e-mail: c.patterson@qub.ac.uk)

\section{Introduction}

Type 1 insulin-dependent diabetes is generally believed to be due to an immune destruction of pancreatic $\beta$ cells in genetically susceptible individuals exposed to environmental risk factors. There has been a rapid increase in the incidence of type 1 diabetes in many European countries in the past few decades. ${ }^{1-4}$ This increase, in conjunction with the lack of complete concordance in monozygotic twin pairs, ${ }^{5-7}$ points to the importance of environmental factors.

Useful clues about these environmental factors may be obtained by studying geographical variation in incidence in relation to the characteristics of different countries. Fundamental to such analyses are high-quality incidence data uniformly collected via a standard protocol from population-based registers. We have previously reported data for the years 1989-90 from 26 registries in the EURODIAB Study Group, and have established that there is a wide range of incidence rates within Europe. ${ }^{8}$ The network has since expanded to include 44 registries, with representation from most European countries and Israel. Incidence data for the 6-year period 1989-94 are presented in this paper.

Differences in the trends in incidence between countries or age-groups may also provide important clues about environmental factors. Some recent reports suggest a higher rate of increase among children under 5 years of age compared with the age groups 5-9 and 10-14 years, ${ }^{9,10}$ which suggests that the environmental factors responsible for the increase may operate early in life. We address this issue in our analysis of the EURODIAB registry data.

\section{Methods}

The establishment of the EURODIAB collaborative group of childhood diabetes registers has been described in detail. ${ }^{8,11}$ Briefly, in 1988, prospective registers of new cases of insulindependent type 1 diabetes mellitus among children aged under 15 years were established in 26 geographically-defined centres in Europe and Israel. Type 1 diabetes was defined on the basis of a clinical diagnosis of idiopathic diabetes made by a physician. Cases secondary to other conditions (having cystic fibrosis or high-dose steroid treatment) were excluded. Date of onset was taken as the date of the first insulin injection. Anonymous data were submitted to a central coordinating office in Odense, Denmark, for data processing and analysis.

Other centres whose registries met the same quality criteria have since joined the group, which now comprises 44 centres. Many of the new participants are from central and eastern Europe, and most European countries are now represented. For the analysis of trends the 40 centres with data for all 6 years in the study period were grouped into countries.

Capture-recapture methodology, ${ }^{12}$ which assumes the availability of independent primary and secondary sources of ascertainment, was used when possible to estimate the completeless of registration. In most centres the primary source of ascertainment was through hospital records or notifications by paediatricians and family doctors. Secondary sources varied, being dependent on local circumstances, but included social insurance schemes, diabetes associations, and prescription data.

Annual estimates of the population resident in each centre's geographically-defined area were used as denominators for the 


\begin{tabular}{|c|c|c|c|c|}
\hline Country & Region & $\begin{array}{l}\text { Number } \\
\text { of } \\
\text { cases }\end{array}$ & $\begin{array}{l}\text { Standardised } \\
\text { incidence rate } \\
(95 \% \mathrm{CI}) \text { per } \\
100000^{*} \\
\end{array}$ & $\begin{array}{l}\text { Completeness of } \\
\text { ascertainment } \\
\text { (period) }\end{array}$ \\
\hline Austria & Whole nation & 753 & $9 \cdot 1(8 \cdot 5-9 \cdot 8)$ & $99 \cdot 7 \%(1991-94)$ \\
\hline Belgium & Antwerp & 112 & $11 \cdot 6(9 \cdot 4-13 \cdot 7)$ & $98 \cdot 7 \%(1989-94)$ \\
\hline \multirow[t]{2}{*}{ Bulgaria } & Western & 303 & $9 \cdot 6(8 \cdot 5-10 \cdot 7)$ & $99.9 \%(1989-94)$ \\
\hline & Eastern & 218 & $6 \cdot 8(5 \cdot 9-7 \cdot 7)$ & $99.9 \%(1989-94)$ \\
\hline Croatia & Zagreb & 83 & $6 \cdot 8(5 \cdot 3-8 \cdot 3)$ & $100 \%(1989-94)$ \\
\hline \multicolumn{4}{|l|}{ Republic } & $100 \%(1989-94)$ \\
\hline Denmark & Four counties & 221 & $16 \cdot 0(13 \cdot 9-18 \cdot 1)$ & $99 \cdot 2 \%(1991-94)$ \\
\hline Estonia & Whole nation & 206 & $10 \cdot 3(8 \cdot 9-11 \cdot 7)$ & $100 \%(1989-94)$ \\
\hline Finland & Two regions & 425 & $40 \cdot 2(36 \cdot 4-44 \cdot 1)$ & $100 \%(1992-93)$ \\
\hline France & Four regions & 837 & $8 \cdot 3(7 \cdot 8-8 \cdot 9)$ & $99.0 \%(1991-94)$ \\
\hline \multirow[t]{2}{*}{ Germany } & Düsseldorf† & 111 & $14 \cdot 0(11 \cdot 4-16 \cdot 6)$ & $92 \cdot 9 \%(1993-94)$ \\
\hline & Baden-Württemberg & 1101 & $11 \cdot 3(10 \cdot 6-12 \cdot 0)$ & $96.5 \%(1989-94)$ \\
\hline \multirow[t]{2}{*}{ Greece } & Attica & 333 & $9.5(8.5-10.5)$ & $100 \%(1993-94)$ \\
\hline & $\begin{array}{l}\text { Five northern } \\
\text { regions }\end{array}$ & 49 & $6 \cdot 2(4 \cdot 5-8 \cdot 0)$ & $100 \%(1989-94)$ \\
\hline Hungary & 18 counties & 822 & $8.9(8.2-9.5)$ & $99 \cdot 6 \%(1989-94)$ \\
\hline Iceland & Whole nation & 52 & $13 \cdot 5(9 \cdot 8-17 \cdot 2)$ & $100 \%(1989-94)$ \\
\hline Israel‡ & Whole nation & 433 & $5 \cdot 9(5 \cdot 3-6 \cdot 4)$ & $100 \%(1993)$ \\
\hline \multirow[t]{4}{*}{ Italy } & Lombardia & 530 & $7 \cdot 0(6 \cdot 4-7 \cdot 6)$ & NSSA \\
\hline & Lazio & 396 & $8.1(7 \cdot 3-8.9)$ & $100 \%(1993-94)$ \\
\hline & Sardinia & 675 & $36.6(33.9-39.4)$ & $85 \cdot 2 \%(1991-94)$ \\
\hline & Eastern Sicily & 150 & $11 \cdot 4(9 \cdot 5-13 \cdot 2)$ & $98 \cdot 3 \%(1991-94)$ \\
\hline Latvia & Whole nation & 221 & $6 \cdot 6(5 \cdot 8-7.5)$ & $99 \cdot 7 \%(1993-94)$ \\
\hline Lithuania & Whole nation & 368 & $7 \cdot 4(6 \cdot 6-8 \cdot 1)$ & $100 \%(1989-94)$ \\
\hline Luxemboug & Whole nation & 49 & $12 \cdot 1(8 \cdot 7-15 \cdot 5)$ & $100 \%(1993-94)$ \\
\hline Macedonia & Whole nation & 93 & $3 \cdot 2(2 \cdot 5-3 \cdot 8)$ & $100 \%(1989-94)$ \\
\hline Netherlands & Five regions & 421 & $13 \cdot 0(11 \cdot 8-14 \cdot 3)$ & $95.9 \%(1991-94)$ \\
\hline Norway & Eight counties & 491 & $21 \cdot 2(19 \cdot 3-23 \cdot 1)$ & $99.9 \%(1992-94)$ \\
\hline \multirow[t]{4}{*}{ Poland } & $\begin{array}{l}\text { Eight western } \\
\text { provinces }\end{array}$ & 542 & $6 \cdot 7(6 \cdot 2-7 \cdot 3)$ & $100 \%(1991-94)$ \\
\hline & Three cities & 312 & $6 \cdot 1(5 \cdot 4-6 \cdot 8)$ & $100 \%$ (1989-94) \\
\hline & Gliwice & 316 & $5 \cdot 4(4 \cdot 8-6 \cdot 0)$ & NSSA \\
\hline & Bialystok§ & 31 & $5.5(3.5-7 \cdot 4)$ & $100 \%(1994)$ \\
\hline \multirow[t]{3}{*}{ Portugal } & Madeira & 24 & $6 \cdot 9(4 \cdot 1-9 \cdot 6)$ & $100 \%(1993-94)$ \\
\hline & Portalegre & 25 & $19 \cdot 0(11 \cdot 5-26 \cdot 5)$ & $94.0 \%(1989-94)$ \\
\hline & Algarve & 51 & $13 \cdot 6(9 \cdot 8-17 \cdot 3)$ & $85 \cdot 1 \%(1991-94)$ \\
\hline Romania & Bucharest & 138 & $5 \cdot 0(4 \cdot 1-5 \cdot 8)$ & $100 \%(1989-94)$ \\
\hline Slovakia & Whole nation & 656 & $8 \cdot 4(7 \cdot 7-9 \cdot 0)$ & $100 \%$ (1989-94) \\
\hline Slovenia & Whole nation & 186 & $7 \cdot 6(6.5-8.7)$ & $100 \%(1992-94)$ \\
\hline Spain & Catalonia & 839 & $12 \cdot 3(11 \cdot 4-13 \cdot 1)$ & $98 \cdot 4 \%(1991-94)$ \\
\hline Sweden & Stockholm county & 451 & $25 \cdot 8(23 \cdot 4-28 \cdot 2)$ & $100 \%(1993-94)$ \\
\hline Switzerland\| & Whole nation & 353 & $7.9(7.1-8.7)$ & NSSA \\
\hline United & Northern Ireland & 462 & $19 \cdot 6(17 \cdot 8-21 \cdot 4)$ & $98.6 \%(1989-94)$ \\
\hline \multirow[t]{3}{*}{ Kingdom } & Oxford & 542 & $17 \cdot 6(16 \cdot 1-19 \cdot 1)$ & NSSA \\
\hline & Leicester & 169 & $15 \cdot 9(13 \cdot 5-18 \cdot 3)$ & $100 \%(1989-93)$ \\
\hline & Leeds & 668 & $15 \cdot 7(14.5-16.9)$ & $97.6 \%(1989-94)$ \\
\hline
\end{tabular}

NSSA=no secondary source of ascertainment. *Standardised for age and sex. †1993-94 only. ¥1989-93 only. §1994 only. ||1991-94 only.

\section{Table 1: Summary registration information for 44 EURODIAB} centres

calculation of rates. Age/sex standardised incidence rates were obtained by the direct method with a standard population consisting of equal numbers of children in each of six subgroups defined by age group (0-4, 5-9, and 10-14 years) and sex.

Poisson-regression models were used to study differences in incidence rate between countries and to investigate the trends in incidence rate. Models with terms for sex, age group (0-4, 5-9, and 10-14 years), country, and calendar year were fitted. These models take account of possible differences in age/sex structure in each country's population and permit testing for any linear trend in incidence rate within a country. Further models incorporating interaction terms were used to test for differences in the linear trends between countries, between sexes, and between age groups. Likelihood-ratio $\chi^{2}$ tests were used to compare the fit of nested models and to provide a test of significance for the last term added to the model. Models were fitted by the SAS GENMOD procedure. (SAS system for Windows, release 6.12, SAS Institute Inc, North Carolina, USA.)

\section{Results}

Average annual incidence rates

Table 1 summarises registration for each centre-the number of cases, the standardised average annual incidence rate, and the estimated completeness of

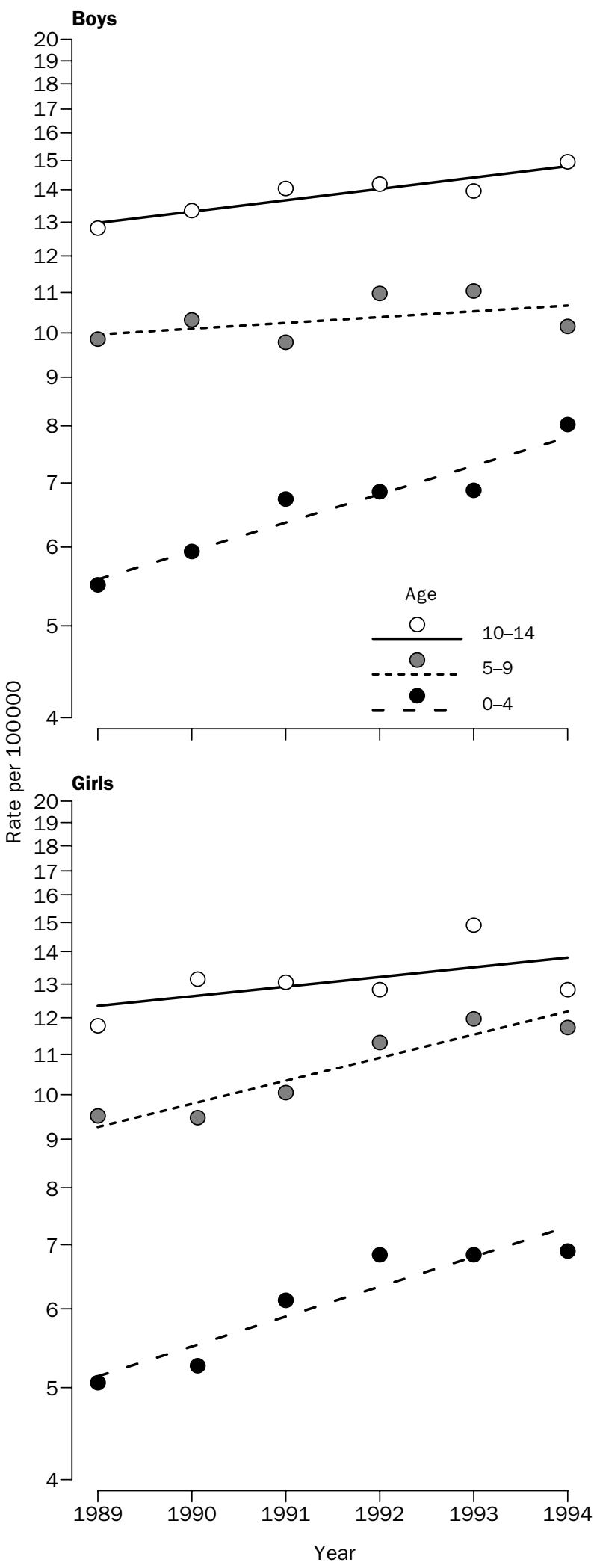

Trends in childhood diabetes incidence in Europe during 1989-94 by age group and sex

ascertainment. Among the 40 centres validating ascertainment, all but four achieved completeness of ascertainment of over $95 \%$. The estimates for some centres exclude the early years of the study period, but estimates for the years 1989-90 have already been published. ${ }^{8}$ The standardised rates varied from $3 \cdot 2$ cases per 100000 per year in the Former Yugoslav Republic of 


\begin{tabular}{|c|c|c|}
\hline Country & $\begin{array}{l}\text { Risk ratio }(95 \% \mathrm{Cl}) \\
\text { per year }\end{array}$ & $\mathbf{p}$ \\
\hline Austria & $1.08(1.03-1.12)$ & 0.0005 \\
\hline Belgium & $1 \cdot 10(0.99-1 \cdot 23)$ & 0.09 \\
\hline Bulgaria (two centres) & $1.05(1.00-1 \cdot 10)$ & 0.06 \\
\hline Croatia & $1.03(0.91-1.17)$ & 0.68 \\
\hline Czech Republic & $1.08(1.04-1.12)$ & 0.0001 \\
\hline Denmark & $0.91(0.84-0.99)$ & 0.02 \\
\hline Estonia & $1.04(0.96-1.12)$ & 0.36 \\
\hline Finland & $0.99(0.93-1.04)$ & 0.62 \\
\hline France & $1.04(1.00-1.09)$ & 0.04 \\
\hline Germany & $1.07(1.03-1 \cdot 10)$ & 0.0004 \\
\hline Greece (two centres) & $0.98(0.93-1.04)$ & 0.57 \\
\hline Hungary & $1.07(1.03-1.12)$ & 0.0006 \\
\hline Iceland & $0.99(0.84-1.16)$ & 0.88 \\
\hline Italy (three centres) & $1.01(0.97-1.04)$ & 0.69 \\
\hline Italy (Sardinia) & $1.01(0.96-1.05)$ & 0.78 \\
\hline Latvia & $0.98(0.90-1.05)$ & 0.53 \\
\hline Lithuania & $1.00(0.94-1.06)$ & 0.91 \\
\hline Luxembourg & $1.04(0.88-1.22)$ & 0.68 \\
\hline Macedonia & $1.01(0.90-1.14)$ & 0.84 \\
\hline Netherlands & $1.02(0.97-1.08)$ & 0.47 \\
\hline Norway & $0.99(0.94-1.04)$ & 0.67 \\
\hline Poland (three centres) & $1.06(1.03-1.10)$ & 0.0006 \\
\hline Portugal (three centres) & $1.13(1.01-1.27)$ & 0.04 \\
\hline Romania & $1.03(0.93-1.14)$ & 0.57 \\
\hline Slovakia & $1.09(1.04-1.14)$ & 0.0003 \\
\hline Slovenia & $1.01(0.93-1.10)$ & 0.86 \\
\hline Spain & $1.00(0.96-1.04)$ & 0.96 \\
\hline Sweden & $1.03(0.98-1.09)$ & 0.25 \\
\hline United Kingdom (four centres) & $1.02(0.99-1.05)$ & 0.14 \\
\hline
\end{tabular}

Table 2: Summary of Poisson-regression analyses showing the incidence trend in each country during 1989-94

Macedonia to $40 \cdot 2$ cases per 100000 in the two regions of Finland. Incidence rates were high in northern and north-western Europe and low in central, southern, and eastern Europe (figure 1). However, Sardinia was a notable exception to this pattern, with a much higher rate than any neighbouring region.

\section{Trends in incidence}

Data for each of the 6 years of the study period were available for all but four of the centres (GermanyDüsseldorf, Israel, Poland-Bialystok, and Switzerland). Poisson-regression models were fitted separately for each country, after data for the centres within each country were pooled. Sardinia, however, was retained as a centre on its own because the incidence there was much higher than for other Italian centres. There was evidence of a significant linear trend in nine of the 29 analyses, all but one showing an increase in incidence rate (table 2). For one country there was evidence of departure from linear trend $(p=0.04)$, but this was no more than might be expected by chance and the annual rates for the country in question showed no consistent pattern. Some central and eastern European countries had rates that increased rapidly (table 2 ).

The results of fitting Poisson-regression models to the data from all countries simultaneously are summarised in table 3. Preliminary model fitting confirmed that there were significant differences in incidence rate between countries and suggested that both sex and age effects differed from country to country. A base model incorporating terms for age, sex, and country was therefore fitted to allow for differences in age/sex specific rates from country to country. Models that specified different patterns of linear trend were then obtained by adding terms to the base model. The test of the overall trend in incidence rate shown in the second line of table 3 is highly significant, with a risk ratio estimate of 1.034 (95\% CI 1.025-1.044), which indicates on average a $3 \cdot 4 \%(2 \cdot 5-4 \cdot 4 \%)$ increase in incidence per year. Table 3 indicates a significant difference in the trends between countries (line 3) and a difference in the trends between age groups (line 4) with no evidence of a difference in trends between boys and girls (line 5) and no evidence that the difference in trends between age-groups varied between boys and girls (line 6). The age-specific annual rates pooled across countries are displayed for boys and girls in figure 2 with a logarithmic vertical scale. Estimates of the rates of increase in the three age groups pooled over countries and sexes were $6 \cdot 3 \%(4 \cdot 1-8 \cdot 5 \%)$ for children aged $0-4$ years, $3 \cdot 1 \%(1 \cdot 5-4 \cdot 8 \%)$ for $5-9$ years, and $2 \cdot 4 \%(1 \cdot 0-3 \cdot 8 \%)$ for $10-14$ years, which shows that in relative terms the highest rates of increase occurred in the youngest age group.

\section{Discussion}

This multicentre study shows a greater than 10-fold range in incidence rate of childhood diabetes in Europe. Such variation seems unlikely to be explained by genetic differences, since Europeans (except for some outlying populations) are more homogeneous compared with the indigenous populations of other continents. ${ }^{13}$ Although the independence of primary and secondary sources of ascertainment cannot easily be verified our assessment of completeness is more thorough than in most previous studies of international variations in incidence, and underascertainment is unlikely to be a major factor in explaining the incidence variation described here.

The rapid increase in incidence is not readily explained by shifts in the frequency of susceptibility genes, and change in environmental factors is a more plausible explanation. A homogeneous pattern of increasing incidence across age groups would suggest that similar environmental exposures operate in each age group. However, our observation of a greater relative increase in incidence in those under 5 years supports the importance of exposures operating early in life. ${ }^{14,15}$ The nature of these exposures is not yet clear, but increased perinatal infections $\mathrm{s}^{16,17}$ or a rapid growth rate in early life ${ }^{18,19}$ could be contributing. 6 years is too short a period to investigate age-group differences in incidence trends

\begin{tabular}{|c|c|c|c|c|c|c|}
\hline \multirow[t]{2}{*}{ Model terms* } & \multicolumn{3}{|c|}{ Goodness of fit } & \multicolumn{3}{|c|}{ Likelihood ratio test for last term } \\
\hline & $x^{2}$ & $\begin{array}{l}\text { Degrees } \\
\text { of freedom }\end{array}$ & $\mathrm{p}$ & $x^{2}$ & $\begin{array}{l}\text { Degrees } \\
\text { of freedom }\end{array}$ & $\mathrm{p}$ \\
\hline 1 Base model & 980.59 & 870 & 0.005 & . & . & .. \\
\hline 2 Base model+year & $930 \cdot 54$ & 869 & 0.07 & $50 \cdot 1$ & 1 & $<0.001$ \\
\hline 3 Base model+year+(year $\times$ country) & $875 \cdot 00$ & 841 & 0.20 & $55 \cdot 5$ & 28 & 0.001 \\
\hline 4 Base model+year+(year $\times$ country)+(year $\times$ age $)$ & $865 \cdot 86$ & 839 & 0.25 & $9 \cdot 14$ & 2 & 0.01 \\
\hline 5 Base model+year+(year $\times$ country $)+($ year $\times$ age $)+($ year $\times$ sex $)$ & $864 \cdot 49$ & 838 & 0.26 & 1.37 & 1 & $0 \cdot 24$ \\
\hline 6 Base model+year+(year $\times$ country $)+($ year $\times$ age $)+($ year $\times$ sex $)+($ year $\times$ age $\times$ sex $)$ & 859.91 & 836 & 0.28 & 4.58 & 2 & $0 \cdot 10$ \\
\hline
\end{tabular}

*Base model=constant+age+sex+age $\times$ sex+country+age $\times$ country+sex $\times$ country+age $\times$ sex $\times$ country. Age: terms for age groups 0-4, 5-9, and 10-14 years; Sex: terms for sex; Country: terms for country; Year: terms for linear trend across the 6 years; Age $\times$ sex: terms for the interaction between age-group and sex.

Table 3: Summary of Poisson-regression analyses of incidence trends for data from $\mathbf{4 0}$ centres grouped into 29 countries 
within each centre. Our modelling compared age-group differences in incidence trends pooled over centres instead, which took account of the different trends in the various centres.

It is tempting to link the rapid increase in incidence rates in some central and eastern European countries with recent political changes. However, the long prediabetic phase thought to be involved in the pathogenesis of this disease ${ }^{20}$ suggests that the factors responsible for these rapid increases may have operated earlier. It will be important to continue monitoring the incidence rate trends in these countries and to compare them with those in Romania and the republics of former Yugoslavia where increases in incidence rate are not yet apparent.

Project co-ordination: A Green, Department of Epidemiology and Social Medicine, University of Aarhus, Denmark; G Brutti, EURODIAB ACE Co-ordinating Office, Odense University Hospital, Denmark.

Writing committee: C C Patterson, Department of Epidemiology and Public Health, Queen's University Belfast, Northern Ireland; G Dahlquist, Department of Clinical Science, Pediatrics, University of Umeå, Sweden; G Soltész, Department of Pediatrics, University of Pécs, Hungary; A Green, Department of Epidemiology and Social Medicine, University of Aarhus, Denmark.

Study centre leaders: Austria-E Schober, Department of Paediatrics, University of Vienna. Belgium - I Weets, C Vandevalle, F Gorus, M Coeckelberghs, M Du Caju, Belgian Diabetes Registry, Brussels. Bulgaria (two centres) - V Christov, Clinic of Endocrinology, University Alexandrov Hospital, Sofia. V Tzaneva, V Iotova, Department of Pediatrics, Clinic of Endocrinology, Medical University, Varna. CroatiaG Roglic, Vuk Vrhovac Institute, Zagreb. Czech Republic-J Vavrinec, Second Clinic of Pediatrics, Charles University, Prague. DenmarkB S Olsen, A J Svendsen, J Kreutzfeldt, E Lund, Department of Pediatrics, KAS-Glostrup. Estonia-T Poodar, Hospital of Endocrinology, Tartu. Finland-J Tuomilehto, M Karvonen, Diabetes and Genetic Epidemiology Unit, National Public Health Institute, Helsinki. France - C Levy-Marchal, P Czernichow, J Doutreix, INSERM U457, Service d'Endocrinologie et Diabétologie Pédiatrique, Hôpital Robert Debré, Paris. Germany (two centres) - G Giani, Diabetes Research Institute, Düsseldorf; A Neu, Tübingen Kinderklinik-Sektion Päd Endokrinol, Eberhard-Karls-Universität. Greece (two centres) - C Bartsocas, K Kassiou, C Dacou-Voutetaki, A C Kafourou, A Al-Qadreh, C Karagianni, Department of Pediatrics, National University of Athens; N Papazoglou, General Hospital Agios Pavlos, Thessaloniki. HungaryG Soltész, Department of Paediatrics, University of Pécs. IcelandA V Thorsson, Department of Pediatrics, University of Iceland, Reykjavik. Israel-Z Laron, O Gordon, Y Albag, I Shamis, Paediatric Endocrinology and Diabetes Reseach Unit, Petah Tikva. Italy (four centres)G Chiumello, Clinica Pediatrica III, Istituto Scientifico H San Raffaele, Milano; P Pozzilli, N Visalli, L Sebastiani, G Marietti, R Buzzetti, Universitá Campus Biomedico, Rome; M Songini, A Casu, A Marinaro, R Ricciardi, M A Zedda, A Milia, Department of Internal Medicine, Hospital San Michele, Cagliari; F Purrello, M Arpi, G Fichera, M Mancuso, C Lucenti, Department of Endocrinology, Ospedale Garibaldi, Catania. Latvia-G Brigis, Public Health and Epidemiology, Latvian Academy of Medicine, Riga. Lithuania-B Urbonaité, Institute of Endocrinology, Kaunas Medical Academy. Luxembourg - C De Beaufort, Clinique Pediatrique de Luxembourg. Macedonia-M Kocova, Pediatric Clinic, Medical Faculty, University of Skopje. Netherlands-M Reeser, Juliana Children's Hospital, The Hague. Norway - G Joner, Departmen of Community Health, Folkehelsa-Epidemiology, Oslo. Poland (four centres) - D Woznicka, Pediatrics, Endocrinology and Diabetes, University of Medical Sciences, Poznan; Z Szybinski, Department of Endocrinology, Jagiellonian University, Krakow; P Jarosz-Chobot, Department of Children's Endocrinology, Silesian School of Medicine, Katowice; I Kinalska, Department of Endocrinology, University Hospital, Bialystok. Portugal (three centres) - S Abreu, Unidade de Endocrinologia, Centro Hospitalar do Funchal, Madeira; C Menezes, Servico de Medicin Interna, Hospital Distrital de Portalegre; E A Pina, Servico de Medicina, Hospital Distrital de Faro. Romania-C Ionescu-Tirgoviste, Department of Nutrition and Metabolic Disease, University of Bucharest. SlovakiaD Michalková, P Hlava, M Mikulecký, JČernay, First Pediatric Clinic, University Komensky, Bratislava. Slovenia-C Krzisnik, T Battelino, N Bratina-Ursic, Endocrine, Diabetes and Metabolic Diseases, University Medical Centre, Ljubljana. Spain - A Goday, Servicio d'Endocrinologia,
Hospital del Mar, Barcelona. Sweden-G Dahlquist, Department of Clinical Science, Pediatrics, University of Umeå. Switzerland-E Schönle, Univ-Kinderklinik Eleonoren-Stiftung, Kinderspital Zürich. UK (four centres) - C Patterson, R Greenlees, D Carson, D Hadden, Queen's University Belfast, Royal Victoria Hospital, Belfast; P Bingley, Department of Medicine, Southmead Hospital, University of Bristol; N Raymond, Department of Epidemiology and Public Health, University of Leicester; P McKinney, H Bodansky, C Stephenson, Institute of Epidemiology and Health Services Research, University of Leeds.

\section{Acknowledgments}

This study has been supported in part by the European Community Concerted Action Programme (grants BMH1-CT92-0043 and BMH4-CT96-0577).

\section{References}

1 Bingley PJ, Gale EAM. Rising incidence of IDDM in Europe. Diabetes Care 1989; 12: 289-95.

2 Diabetes Epidemiology Research International Group. Secular trends in incidence of childhood IDDM in 10 countries. Diabetes 1990; 39: 858-64.

3 Karvonen M, Tuomilehto J, Libman I, LaPorte R. A review of the recent epidemiological data on the worldwide incidence of type 1 (insulin-dependent) diabetes mellitus. Diabetologia 1993; 36: 883-92.

4 Green A, Sjolie AK, Eshoj O. The epidemiology of diabetes mellitus. In: Pickup JC, Williams G, eds. Textbook of diabetes. Oxford: Blackwell Science, 1997.

5 Leslie RDG, Lo SSS, Hawa M, et al. Lessons on the etiology of insulin-dependent diabetes from twin studies. In: Levy-Marchal C, Czernichow P, eds. Epidemiology and etiology of insulin-dependent diabetes in the young. Basle: Karger, 1992.

6 Kaprio J, Tuomilehto J, Koskenvuo M, et al. Concordance for type 1 (insulin-dependent) and type 2 (non-insulin dependent) diabetes mellitus in a population-based cohort of twins in Finland. Diabetologia 1992; 35: 1060-67.

7 Kyvik KO, Green A, Beck-Nielsen H. Concordance rates of insulin dependent diabetes mellitus: a population based study of young Danish twins. BMF 1995; 311: 913-17.

8 Green A, Gale EAM, Patterson CC, for the EURODIAB ACE Study Group. Incidence of childhood-onset insulin-dependent diabetes mellitus: the EURODIAB ACE study. Lancet 1992; 339: 905-09.

9 Tuomilheto J, Virtala E, Karvonen M, et al. Increase in incidence of insulin-dependent diabetes mellitus among children in Finland. Int $\mathcal{F}$ Epidemiol 1995; 24: 984-92.

10 Gardner SG, Bingley PJ, Sawtell PA, Weeks S, Gale EAM. Rising incidence of insulin dependent diabetes in children aged under 5 years in the Oxford region: time trend analysis. BMF 1997; 315: 713-17.

11 Levy-Marchal C, Patterson C, Green A, on behalf of the EURODIAB ACE Study Group. Variation by age-group and seasonality at diagnosis of childhood IDDM in Europe. Diabetologia 1995; 38: 823-30.

12 Bishop YMM, Fienberg SE, Holland PW. Estimating the size of a closed population. Discrete multivariate analysis: theory and practice. Cambridge, Massachusetts, MIT Press, 1975.

13 Cavalli-Sforza LL, Piazza A. Human genomic diversity in Europe: a summary of recent research and prospects for the future. Eur f Hum Genet 1993; 1: 3-18.

14 Leslie RD, Elliott RB. Early environmental events as a cause of IDDM: evidence and implications. Diabetes 1994; 43: 843-50.

15 Dahlquist GG. Viruses and other perinatal exposures as initiating events for beta-cell destruction. Ann Med 1997; 29: 413-17.

16 Dahlquist GG, Ivarsson S, Lindberg B, Forsgren M. Maternal enteroviral infection during pregnancy as a risk factor for childhood IDDM. A population-based case-control study. Diabetes 1995; 44: 408-13

17 Hyöty H, Hiltunen M, Knip M, et al. A prospective study of the role of Coxsackie B and other enterovirus infections in the pathogenesis of IDDM. Diabetes 1995; 44: 652-57.

18 Blom L, Persson LA, Dahlquist G. A high linear growth is associated with an increased risk of childhood diabetes mellitus. Diabetologia 1992; 35: 528-33.

19 Johansson C, Samuelsson U, Ludvigsson J. A high weight gain early in life is associated with an increased risk of type 1 (insulin-dependent) diabetes mellitus. Diabetologia 1994; 37: 91-94.

20 Gorsuch AN, Spencer KM, Lister J, et al. Evidence for a long prediabetic period in type I (insulin-dependent) diabetes mellitus. Lancet 1981; ii: 1363-65. 